\title{
Immune Deficiency in Mouse Models for Inherited Peripheral Neuropathies Leads to Improved Myelin Maintenance
}

\author{
Christoph D. Schmid,, ${ }^{1,2}$ Martina Stienekemeier, ${ }^{1}$ Stephan Oehen, ${ }^{3}$ Frank Bootz, ${ }^{4}$ Jürgen Zielasek, ${ }^{1}$ \\ Ralf Gold, ${ }^{1}$ Klaus V. Toyka, ${ }^{1}$ Melitta Schachner, ${ }^{5}$ and Rudolf Martini, ${ }^{1,2}$
}

${ }^{1}$ Department of Neurology, University of Würzburg, D-97080 Würzburg, Germany, ${ }^{2}$ Department of Neurobiology, Swiss Federal Institute of Technology, CH-8093 Zürich, Switzerland, Institutes of ${ }^{3}$ Experimental Immunology and ${ }^{4}$ Laboratory Animal Science, University of Zürich, CH-8092 Zürich, Switzerland, and ${ }^{5}$ Zentrum für Molekulare Neurobiologie, University of Hamburg, D-20246 Hamburg, Germany

\begin{abstract}
The adhesive cell surface molecule $P_{0}$ is the most abundant glycoprotein in peripheral nerve myelin and fulfills pivotal functions during myelin formation and maintenance. Mutations in the corresponding gene cause hereditary demyelinating neuropathies. In mice heterozygously deficient in $\mathrm{P}_{0}\left(\mathrm{P}_{0}{ }^{+/-}\right.$mice), an established animal model for a subtype of hereditary neuropathies, T-lymphocytes are present in the demyelinating nerves. To monitor the possible involvement of the immune system in myelin pathology, we cross-bred $\mathrm{P}_{0}{ }^{+/-}$mice with null mutants for the recombination activating gene 1 (RAG-1) or with mice deficient in the T-cell receptor $\alpha$-subunit. We found that in $\mathrm{P}_{\mathrm{O}}{ }^{+/-}$mice myelin degeneration and impairment of nerve con-
\end{abstract}

Myelin protein zero (MPZ or $\mathrm{P}_{0}$ ), the most abundant glycoprotein of the myelin sheath of peripheral nerves, is a transmembrane adhesion molecule of the Ig superfamily that fulfills multiple functions during myelin development and maintenance (for review, see Martini and Schachner, 1997). Its pivotal role in the peripheral nervous system is reflected by the fact that mutations in the corresponding gene cause inherited neuropathies, such as Charcot-Marie-Tooth (CMT) disorder, type 1B, the DéjérineSottas syndrome, and congenital hypomyelination (for review, see De Jonghe et al., 1997; Martini et al., 1998; Nelis et al., 1999). These disorders are typically associated with muscular weakness and atrophy, sensory dysf unction, and skeletal deformities. Biopsies from CMT1B patients revealed that, dependent on the mutation in the $P_{0}$ gene, divergent pathological hallmarks can be found. Such hallmarks comprise either formation of myelin tomacula, i.e., focally thickened myelin sheaths of reduced stability or, alternatively, myelin decompaction and demyelination

\footnotetext{
Received June 14, 1999; revised Sept. 10, 1999; accepted Oct. 22, 1999.
}

This study was supported by the Swiss National Science Foundation (NF 3145890.95 to R.M.), Gemeinnützige Hertie-Stiftung (GHS 2/3378/96 to R.M. and M. Sch.), the Deutsche Forschungsgemeinschaft (Priority Program "Microglia," MA1053/3-1, to R.M.), Research Funds of the University of Würzburg European Union (Clinical, genetic and functional analysis of peripheral neuropathies), and by the German Ministry for Education and Research. We are grateful to Professor Rolf Zinkernagel (University of Zürich) for valuable advice and discussions, Heinrich Blazyca and Kathrin Rohner for excellent technical assistance, and Dr. Stefano Carenini for discussions. We are indebted to Dr. Imme Haubitz (Department of Mathematics and Statistics, University of Würzburg) for performing the statistical analysis of the quantification of immune cells in peripheral nerves and of the splenocyte proliferation assay. We also thank Dr. M. Koltzenburg for the possibility to use electronic equipment.

Correspondence should be addressed to Rudolf Martini, Department of Neurology, Section of Developmental Neurobiology, University of Würzburg, D-97080 Würzburg, Germany. E-mail: neuk176@rzkli.uni-wuerzburg.de.

Copyright (C) 2000 Society for Neuroscience $0270-6474 / 00 / 200729-07 \$ 15.00 / 0$ duction properties is less severe when the immune system is deficient. Moreover, isolated T-lymphocytes from $\mathrm{P}_{\mathrm{o}}{ }^{+/-}$mice show enhanced reactivity to myelin components of the peripheral nerve, such as $P_{0}, P_{2}$, and myelin basic protein. We hypothesize that autoreactive immune cells can significantly foster the demyelinating phenotype of mice with a primarily genetically based peripheral neuropathy.

Key words: Charcot-Marie-Tooth disease; myelin degeneration; Schwann cell; $P_{O}$; myelin protein zero; immune system; immune deficiency; T-lymphocytes; macrophages; electron microscopy; electrophysiology
(Thomas et al., 1994; Gabreëls-Festen et al., 1996; Tachi et al., 1997). Recently, we have shown that heterozygous $P_{0}$ null mutant mice $\left(\mathrm{P}_{0}{ }^{+/-}\right)$are appropriate models for mild CMT1B forms with an initially normal myelin formation followed by myelin decompaction and demyelination starting at 4 months of life (Martini et al., 1995a; for review, see Martini, 1997). Although it is well accepted that various heterozygous mutations or the reduction in gene dosage of $\mathrm{P}_{0}$ lead to demyelination (for review, see Martini et al., 1998), the molecular and cellular mechanisms that lead to myelin degeneration are not yet understood. Based on the observation that nerves of patients suffering from inherited neuropathies (Schmidt et al., 1996) or nerves of $\mathrm{P}_{0}{ }^{+/-}$mice contain endoneurial T-lymphocytes (Schmid et al., 1996; Shy et al., 1997), we tested the hypothesis that the immune system might be involved in the development of the demyelinating phenotype. We, therefore, cross-bred $\mathrm{P}_{0}{ }^{+/-}$mice with homozygous null mutants for the recombination activating gene 1 (RAG-1) or with mice deficient in the T-cell receptor $\alpha$-subunit (TCR $\alpha$ ), i.e., with mutants that are deficient in mature $\mathrm{T}$ - and B-lymphocytes or only T-lymphocytes, respectively. We found that, in the absence of an intact immune system, myelin degeneration in $\mathrm{P}_{0}{ }^{+/-}$mice is significantly reduced in comparison to $\mathrm{P}_{0}{ }^{+-}$mice with normal immune cells. Moreover, isolated T-lymphocytes from $\mathrm{P}_{0}{ }^{+/-}$ mice show enhanced reactivity to myelin components of the peripheral nerve, such as $\mathrm{P}_{0}, \mathrm{P}_{2}$, and myelin basic protein (MBP). We conclude that the immune system may be functionally involved in the demyelinating phenotype of mice with a primarily genetically mediated peripheral neuropathy.

\section{MATERIALS AND METHODS}

Animals and determination of genotypes. Mice deficient in the gene for protein zero $\left(\mathrm{P}_{0}^{---}\right.$; Giese et al., 1992) or the recombination activating 
gene 1 (RAG-1 ${ }^{-/-}$; Mombaerts et al., 1992) were generated as described previously and backcrossed to the C57BL/6 strain for six to eight generations. Double mutants were generated by cross-breeding heterozygous $\mathrm{P}_{0}$-mutants $\left(\mathrm{P}_{0}{ }^{+/-}\right.$mice $)$with $\mathrm{RAG}-1^{-/-}$mice under specific pathogenfree conditions (Institute of Laboratory Animal Science, University of Zürich) in analogy to the breeding protocol described previously (Martini et al., 1995b; Carenini et al., 1997). Mice deficient for the T-cell receptor $\alpha$ subunit (TCR $\alpha^{-/-}$; Philpott et al., 1992) were bred on a mixed background (129/Ola/Hsd, BALB/c, C57Bl/6) and cross-bred with $\mathrm{P}_{0}^{+/-}$ mice as described above. Genotypes of $\mathrm{P}_{0}$-mutants were determined by conventional PCR using oligonucleotides 5'-TCAGTTCCTTGTCCCCCGCTCTC-3'，5'-GGCTGCAGGGTCGCTCGGTGTTC-3', and 5'-ACTTGTCTCTTCTGGGTAATCAA-3' leading to 334 or $500 \mathrm{bp}$ products for the $\mathrm{P}_{0}$ null mutation or wild-type allele, respectively. The phenotype of the RAG-1 or the TCR $\alpha$ null mutation was determined by fluorescence activated cell sorting (FACS) analysis of peripheral blood cells stained with phycoerythrin (PE)-coupled anti-CD4 and fluoresceinisothiocyanate-coupled anti-CD8 antibodies (PharMingen, Hamburg, Germany) using a FACScan instrument (Becton Dickinson, Heidelberg, Germany). To rule out the possibility that the effects observed were a consequence of differences in the genetic background, all pathological alterations were investigated in littermates. For all pathological studies, the femoral quadriceps nerve was chosen that contains $\sim 500$ myelinated axons in wild-type mice (Lindberg et al., 1999), thus being an ideal paradigm for quantitative analyses. All experiments described here on animals were approved by the Veterinary Administration of Zürich, Switzerland and by the Regierung von Unterfranken (Würzburg, Germany).

Immunohistochemistry. Fourteen-micrometer-thick serial sections from fresh frozen femoral nerve were immunostained as previously described (Guénard et al., 1999). For detection of T-lymphocytes, anti-mouse CD8 (1:50 of supernatants of hybridoma cell lines TS169; Cobbold et al., 1984) were used. For detection of macrophages, anti-mouse F4/80 (1:500; Serotec, Oxford, UK) was used. Sections of spleen of wild-type mice were used as positive controls, and for negative control the primary antibody was omitted. Positive profiles were counted on cryosections using a Zeiss Axiophot microscope, and the mean number of positive profiles per $\mathrm{mm}^{2}$ section was calculated. Statistical analysis of the number of immune cells in cryosections was performed by a two-way ANOVA test.

Electrophysiology. Nerve conduction properties of sciatic nerves from 13-month-old myelin mutants homozygously deficient in RAG-1 $\left(\mathrm{P}_{0}{ }^{+/-} /\right.$ RAG-1 ${ }^{-/-}$) and myelin mutants heterozygously deficient in RAG-1 $\left(\mathrm{P}_{0}{ }^{+/-} / \mathrm{RAG}-1^{+/-}\right)$as well as from myelin wild-type mice either homozygously or heterozygously deficient in RAG-1 $\left(\mathrm{P}_{0}{ }^{+/+} / \mathrm{RAG}^{-1} 1^{-/}\right.$, $\mathrm{P}_{0}{ }^{+/+} / \mathrm{RAG} 1^{+/-}$) were determined by established electrophysiological methods as previously described in detail (Zielasek et al., 1996). In brief, anesthetized mice (Hypnorm, Janssen, Belgium) received subcutaneous stimulating electrodes at the sciatic notch (proximal stimulation) and above the ankle (distal stimulation). Recording electrodes were placed subcutaneously close to the hallux and between digits 2 and 3. Studies were performed with a current $50 \%$ higher than that needed to elicit maximal stimulation. In all experiments, the investigator (J.Z.) was not aware of the genotype of the mice. For motor nerve conduction studies, the following parameters were measured: proximal and distal M-response latencies, proximal and distal F-wave latencies, and amplitudes of compound muscle action potentials. Nerve conduction velocities were calculated from the latency measurements and the distance of the stimulation sites. In analogy to the different $\mathrm{P}_{0} / \mathrm{RAG}-1$ mutants, nerve conduction properties from 13-month-old $\mathrm{P}_{0}^{+/-} / \mathrm{TCR} \alpha^{-/-}, \mathrm{P}_{0}^{+/-}$ $\mathrm{TCR} \alpha^{+/-}, \mathrm{P}_{0}^{+/+} / \mathrm{TCR} \alpha^{-/-}$and $\mathrm{P}_{0}^{+/+} / \mathrm{TCR} \alpha^{+/-}$mice were determined. Statistical analysis was performed using a one-sided $t$ test.

Tissue preservation for electron microscopy. Femoral nerves of mice were processed for light and electron microscopy as previously described (Martini et al., 1995b; Lindberg et al., 1999). Briefly, mice were transcardially perfused with $0.1 \mathrm{M}$ cacodylate buffer containing $4 \%$ paraformaldehyde and $2 \%$ glutaraldehyde, and nerves were post-fixed in the same fixative overnight. After osmification and dehydration, nerves were embedded in Spurr's medium.

Morphometry. For light microscopy, semithin sections $(0.5-\mu \mathrm{m}$-thick) were stained with alkaline methylene blue. For electron microscopy, ultrathin sections $(80 \mathrm{~nm})$ were contrasted with lead citrate. Quantification of total nuclei and myelin competent axons was performed on cross sections of the quadriceps branch of the femoral nerve. For this purpose, all nuclei were counted on semithin sections at a final magnification of $600 \times$. The number of myelin competent axons $(>2 \mu \mathrm{m}$ in diameter $)$ that were not or only thinly myelinated (less than five turns) was determined by electron microscopy. Analysis of morphometric parameters such as the g-ratio (myelin thickness; Friede, 1972), the diameter of axons (Friede, 1972), and the endoneurial space was done by electron microscopy on randomly selected parts of ultrathin cross sections of the quadriceps branch of the femoral nerve. The endoneurial space was determined as the fraction of total nerve area not occupied by fibers. Electron micrographs of two randomly selected parts per nerve cross section were digitized with a scanner (HP 4C). Morphometric parameters were evaluated at a final magnification of $8000 \times$ using the Image Tool Application, version 1.28 program (University of Texas UTHSCSA). Statistical significance of differences between mean values of $\mathrm{P}_{0}{ }^{+/-} / \mathrm{RAG} 1^{-1-}$ versus $\mathrm{P}_{0}{ }^{+/-} / \mathrm{RAG} 1^{+/-}$mice was determined by double-sided Student's $t$ test using Microsoft Excel software.

Culture of splenocytes and proliferation assay. Splenocytes from four myelin wild-type $\left(\mathrm{P}_{0}^{+/+}\right)$and four $\mathrm{P}_{0}{ }^{+/}$mice at the age of 8 months were seeded into 96-well microtiter plates at a density of $1.5 \times 10^{6} / \mathrm{ml}$ (Nunc, Wiesbaden, Germany). Splenocytes were exposed to recombinant human (rh) $\mathrm{P}_{0}, \mathrm{rhP}_{2}$ (Weishaupt et al., 1995), rat MBP $(10 \mu \mathrm{g} / \mathrm{ml}$ each), or concanavalin A (Con A; $2.5 \mu \mathrm{g} / \mathrm{ml}$ ), as described (Pette et al., 1990; Stienekemeier et al., 1999) except that we used $1 \%$ autologous serum and added $5 \times 10^{-5}$ M 2-mercaptoethanol. After $3 \mathrm{~d}$, murine interleukin (IL)-2 (2.5 ng/ml; R \& D Systems, Wiesbaden, Germany) was added. On day 8 , the nonadherent cells from each plate were split into two new microtiter plates. Cells were reactivated on day 14 by addition of irradiated, syngeneic splenocytes to both subcultures, whereas the respective antigens were added to only one as described for the split well technique (Pette et al., 1990). After 48 hr, cells were pulsed with tritiated thymidine and harvested $16 \mathrm{hr}$ later (Stienekemeier et al., 1999). Corresponding cultures were compared for specific proliferation. Wells showing a thymidine incorporation of $>1000$ counts per minute and a stimulation index of $>3$ in comparison to control wells without antigen were considered positive. For each antigen, at least 96 primary wells were screened. Statistical analysis was performed with the Mann-Whitney $U$ test using the Prism computer program (Graph Pad, San Diego, CA). $p$ values $<$ 0.05 were considered statistically significant.

\section{RESULTS}

\section{Quantification of immune cells in peripheral nerves}

In an attempt to confirm previous observations of the presence of immune system derived cells within the nerves of adult $\mathrm{P}_{0}{ }^{+/-}$ mice (Schmid et al., 1996), markers for lymphocytes (CD8; Brideau et al., 1980) or for mouse macrophages (F4/80; Austin and Gordon, 1981) were used. At the age of 4 and 6 months, three $\mathrm{P}_{0}{ }^{+/+}$and three $\mathrm{P}_{0}{ }^{+/-}$mice were considered. At older ages $(8$ and 21 months), two mice of each genotype were included, with the exception of three $\mathrm{P}_{0}^{+/-}$mice investigated at 21 months. In cross sections of femoral nerves of 4- to 21-month-old mice, CD8positive cells were always rounded, whereas F4/80-positive cells were usually ramified or showed at least a few slender processes. During the analysis, the investigator (C.D.S.) was not aware of the genotype of the nerve sections. In general, CD8-positive cells as well as F4/80-positive cells were predominantly detectable in the endoneurium of nerves. When comparing nerves from $\mathrm{P}_{0}{ }^{+/-}$ versus $\mathrm{P}_{0}{ }^{+/+}$mice, there was no quantitative difference in the number of CD8-positive cells at 4 months of age (Fig. 1, top left diagram), a stage where the very first pathological changes are detectable in $\mathrm{P}_{0}^{+/-}$mice (Martini et al., 1995a). However, at 6 months and older, the number of CD8-positive profiles was always higher in nerves from $\mathrm{P}_{0}{ }^{+-}$versus $\mathrm{P}_{0}{ }^{++}$mice, although there was considerable heterogeneity. This heterogeneity was possibly caused by the previously reported nonuniform distribution of lymphocytes along the course of the nerve (Shy et al., 1997; Fig. 1, top left diagram). F4/80-positive endoneurial profiles outnumbered CD8-positive cells by a factor of $\sim 20$. In contrast to CD8-positive profiles, the numbers of F4/80-positive cells were already elevated in 4-month-old $\mathrm{P}_{0}{ }^{+/-}$mice when compared to age-matched $\mathrm{P}_{0}{ }^{+/+}$mice (Fig. 1, top right diagram). 


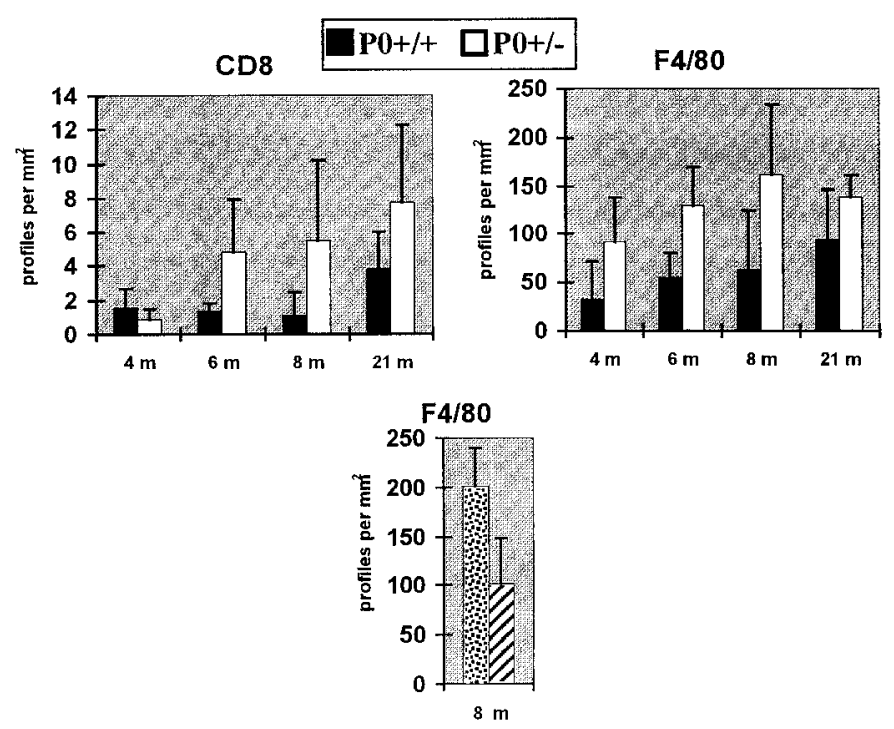

Figure 1. Quantification of CD8- and F4/80-positive cells in cryosections of quadriceps nerves from $\mathrm{P}_{0}{ }^{+/+}$(top diagrams, filled bars) and $\mathrm{P}_{0}{ }^{+/-}$mice (top diagrams, open bars) and quantification of $\mathrm{F} 4 / 80$-positive cells in quadriceps nerves from $\mathrm{P}_{0}{ }^{+/-} / \mathrm{TCR} \alpha^{+/-}$(bottom diagram, stippled bars) and $\mathrm{P}_{0}^{+1-} / \mathrm{TCR} \alpha^{-1-}$ mice (bottom diagram, hatched bars). Top diagrams, Note elevated levels of immune-derived cells in $\mathrm{P}_{0}{ }^{+-}$mice. Statistical significance was achieved for F4/80-positive cells, but not for CD8-positive cells, which might be related to the heterogeneous distribution of the lymphocytes along the nerve. Error bars indicate SD. Bottom diagram, Note reduced levels of F4/80-positive cells in quadriceps nerves of $\mathrm{P}_{0}{ }^{+/-} / \mathrm{TCR} \alpha^{-1-}$ versus $\mathrm{P}_{0}{ }^{+/-} / \mathrm{TCR} \alpha^{+/-}$mice at 8 months of age. Error bars indicate SD. $p<0.05$ (Student's $t$ test).

Statistical analysis comparing the numbers of immune cells in $\mathrm{P}_{0}{ }^{+/+}$versus $\mathrm{P}_{0}{ }^{+/-}$mice by a two-way ANOVA test considering all time points investigated resulted in $p$ values of 0.0035 and 0.064 for F4/80- and CD8-positive cells, respectively. Thus, the difference of F4/80-positive cells in $\mathrm{P}_{0}{ }^{+/}$versus $\mathrm{P}_{0}{ }^{+/-}$mice was statistically significant, whereas the difference of the CD8-positive cells did not reach statistical significance, which might be related to the considerable heterogeneity in the distribution of the cells (see above).

\section{Generation of double mutants}

By cross-breeding $\mathrm{P}_{0}^{+/-}$mice with RAG-deficient (RAG-1 ${ }^{-/-}$) mice and intercrossing the individuals of the F1 generation, we obtained an F2 generation with myelin mutants homozygously deficient in RAG-1 $\left(\mathrm{P}_{0}{ }^{+/-} / \mathrm{RAG}^{-1-}{ }^{-/}\right)$and myelin mutants heterozygously deficient in RAG- $1\left(\mathrm{P}_{0}{ }^{+/-} / \mathrm{RAG}-1^{+/-}\right)$. In addition, $\mathrm{P}_{0}{ }^{+/+}$mice either homozygously or heterozygously deficient in RAG-1 $\left(\mathrm{P}_{0}{ }^{+/+} / \mathrm{RAG}-1^{-/-}, \mathrm{P}_{0}^{+/+} / \mathrm{RAG}^{+} 1^{+/-}\right)$were obtained. $\mathrm{RAG}^{-1-}$ mice are reported to be deficient for mature $\mathrm{T}$ - and B-lymphocytes (Mombaerts et al., 1992). Based on FACS and in agreement with previous reports (Mombaerts et al., 1992), CD4and CD8-single positive T-lymphocytes in peripheral blood were not detectable in RAG- $1^{-/-}$genotypes. In RAG- $1^{+/-}$mice, the number of CD4- and CD8-positive T-lymphocytes was indistinguishable from values from $\mathrm{RAG}-1^{+/+}$genotypes reflecting normal immune cell development (Mombaerts et al., 1992). A corresponding pattern of cross-breeding of $\mathrm{P}_{0}^{+/-}$mice was performed with mice deficient in the TCR $\alpha$-subunit (TCR $\alpha^{-1-}$ mice) that lack mature TCR $\alpha \beta$-lymphocytes, but contain B-lymphocytes and small populations of TCR $\beta$ - and TCR $\gamma \delta$-Tlymphocytes (Philpott et al., 1992; Neuhaus et al., 1996; see Materials and Methods).

\section{Deficiency in the RAG-1 gene leads to milder pathological changes in $\mathrm{P}_{0}^{+/-}$mice}

We first investigated semithin sections of femoral quadriceps nerves of $\mathrm{P}_{0}{ }^{+/+} / \mathrm{RAG}-1^{+/-}$and $\mathrm{P}_{0}{ }^{+/+} / \mathrm{RAG}-1^{-/-}$mice at the age of 13 months. We found that, independent of the RAG-1 genotype, these nerves were of normal phenotype with thick myelin, overall compact appearance with small endoneurial spaces between the nerve fibers, and absence of features indicative of demyelination (Table 1, Fig. $2 a, b$ ).

Next, we compared quadriceps femoral nerves from 13-monthold $\mathrm{P}_{0}{ }^{+/-} / \mathrm{RAG}-1^{+/-}$mice with nerves from $\mathrm{P}_{0}^{+/-} / \mathrm{RAG}-1^{-/-}$ littermates. In semithin sections, all mice of $\mathrm{P}_{0}{ }^{+/-}$genotype showed pathological alterations indicative of compromised myelin maintenance (Fig. $2 c, d$ ). However, two principle categories of pathological severity could be distinguished by an investigator who was not aware of the genotype (R.M.). In all cases, the more severely affected nerves were from $\mathrm{P}_{0}{ }^{+/-} / \mathrm{RAG}-1^{+/-}$mice, whereas the nerves with less pronounced pathological alterations were derived from immune-deficient $\mathrm{P}_{0}^{+/-} / \mathrm{RAG}-1^{-/-}$mice (Fig. $2 c, d$ ). The nerves of the latter mutants were characterized by thicker myelin sheaths and significantly lower numbers of cell nuclei (Table 1) that mostly belonged to typical Schwann cell onion bulbs. Such supernumerary Schwann cells are a well established indicator of demyelination in mice and humans (for review, see Martini, 1997) so that their reduced numbers in the $\mathrm{P}_{0}{ }^{+/-} /$ RAG-1 ${ }^{-1-}$ mutants reflect a lower degree of myelin degeneration. As a consequence of the lower number of supernumerary Schwann cells, the nerves of the $\mathrm{P}_{0}{ }^{+/-} / \mathrm{RAG}-1^{-/-}$mice appeared more compact in that the myelinated fibers were separated by smaller endoneurial spaces. The number of myelin-competent, i.e., thick caliber axons was similar in both $\mathrm{P}_{0}{ }^{+/-} / \mathrm{RAG}-1^{+/-}$and $\mathrm{P}_{0}{ }^{+/-} / \mathrm{RAG}-1^{-/-}$mutants (data not shown).

Next, we quantified the pathological alterations in the different mutants by electron microscopy. As exemplified in Figure 2, $e$ and $f$, and in agreement with the light-microscopic findings, pathological features were less severe in $\mathrm{P}_{0}{ }^{+/-} / \mathrm{RAG}-1^{-/-}$versus $\mathrm{P}_{0}{ }^{+/-} /$ RAG- $1^{+/-}$mice (Table 1 ). Particularly striking were the thicker myelin sheaths in the $\mathrm{P}_{0}^{+/-} / \mathrm{RAG}-1^{-/-}$mice, as indicated by their significantly lower g-ratio values (see Materials and Methods) when compared to the $\mathrm{P}_{0}{ }^{+/-} / \mathrm{RAG}-1^{+/-}$littermates. Supporting the impression by light microscopy, the endoneurial space was significantly less expanded in $\mathrm{P}_{0}{ }^{+/-} / \mathrm{RAG}-1^{-/-}$mice in comparison to the $\mathrm{P}_{0}{ }^{+/-} / \mathrm{RAG}-1^{+/-}$littermates when quantified on electron micrographs (Table 1).

We also investigated the number of F4/80-positive macrophages in $\mathrm{P}_{0}^{+/-} / \mathrm{RAG}-1^{-/-}$versus $\mathrm{P}_{0}^{+/-} / \mathrm{RAG}-1^{+/-}$mice. Most interestingly, macrophages were reduced in numbers in one $\mathrm{P}_{0}{ }^{+/-} / \mathrm{RAG}-1^{-/-}$mouse $\left(140\right.$ per $\mathrm{mm}^{2}$ ) versus a $\mathrm{P}_{0}{ }^{+/-} / \mathrm{RAG}-$ $1^{+/-}$littermate $\left(346\right.$ per $\left.\mathrm{mm}^{2}\right)$ at 13 months of age. Although this observation refers to only one individual of each genotype, we consider the reduced number of macrophages in the $\mathrm{P}_{0}{ }^{+/} /$ RAG- $1^{-/-}$mouse as relevant, because analogous investigations in other immune-deficient mice $\left(\mathrm{P}_{0}{ }^{+/-} / \mathrm{TCR} \alpha^{+/-}\right.$and $\mathrm{P}_{0}{ }^{+/-} /$ $\mathrm{TCR} \alpha^{-/-}$mice) with higher numbers of individuals investigated $(n=3)$ revealed similar observations (see below; Fig. 1, bottom diagram).

\section{Deficiency in the TCR $\alpha$ gene leads to milder pathological changes in $\mathbf{P}_{0}{ }^{+/-}$mice}

We also compared quadriceps nerves from 8-month-old $\mathrm{P}_{0}{ }^{+/-} /$ TCR $\alpha^{+/-}(n=4)$ versus $\mathrm{P}_{0}^{+/-} / \mathrm{TCR} \alpha^{-1-}(n=3)$ mice both at the light- and electron-microscopic level. Similar to the findings in 
Table 1. Morphometric analysis of femoral quadriceps nerves from 13-month-old $P_{0} /$ RAG-1 mutants

\begin{tabular}{|c|c|c|c|c|}
\hline Genotype & $\begin{array}{l}\mathrm{P}_{0}^{+/+} / \mathrm{RAG}^{+1-} 1^{+/-} \\
(n=2)\end{array}$ & $\begin{array}{l}\mathrm{P}_{0}^{+/+} / \mathrm{RAG} 1^{-1-} \\
(n=3)\end{array}$ & $\begin{array}{l}\mathrm{P}_{0}^{+/-} / \mathrm{RAG}^{+1-} 1^{+/-} \\
(n=2)\end{array}$ & $\begin{array}{l}\mathrm{P}_{0}^{+/-} / \mathrm{RAG}^{-1-} 1^{-1-} \\
(n=3)\end{array}$ \\
\hline Number of nuclei* & $10.5 \pm 6.4$ & $13.7 \pm 3.2$ & $68.0 \pm 2.8$ & $36.3 \pm 13.5$ \\
\hline Endoneurial space* & $22.5 \pm 0.9$ & $26.4 \pm 3.9$ & $64.1 \pm 1.4$ & $37.8 \pm 5.6$ \\
\hline g-ratio* & $0.74 \pm 0.003$ & $0.73 \pm 0.012$ & $0.81 \pm 0.004$ & $0.71 \pm 0.020$ \\
\hline Axon diameter** & $7.4 \pm 0.2$ & $6.7 \pm 0.2$ & $5.6 \pm 0.2$ & $5.1 \pm 0.7$ \\
\hline
\end{tabular}

*Values from $\mathrm{P}_{0}^{+/-} / \mathrm{RAG}-1^{+/-}$mice are significantly different from values from $\mathrm{P}_{0}^{+/-} / \mathrm{RAG}-1^{-/-}$littermates $(p<0.05)$.

$* *$ Only axons with compacted myelin were measured. Mean values \pm SDs are indicated. Values in brackets are numbers of animals investigated.

$\mathrm{P}_{0}{ }^{+/-} / \mathrm{RAG}-1^{+/-}$and $\mathrm{P}_{0}^{+/-} / \mathrm{RAG}-1^{-/-}$mice, the pathological alterations in the $\mathrm{P}_{0}^{+/-} / \mathrm{TCR} \alpha^{-/-}$mice were less pronounced than in the $\mathrm{P}_{0}^{+/-} / \mathrm{TCR} \alpha^{+/-}$littermates. For instance, in $\mathrm{P}_{0}^{+/-} /$ $\mathrm{TCR} \alpha^{-1-}$ mice, the number of Schwann cell nuclei was significantly reduced when compared to values from $\mathrm{P}_{0}{ }^{+/-} / \mathrm{TCR} \alpha^{+/-}$ littermates $(26.7 \pm 11.2$ vs $53.8 \pm 13.3 ; p<0.05)$. Furthermore, the endoneurial space was less expanded in $\mathrm{P}_{0}{ }^{+/-} / \mathrm{TCR} \alpha^{-1-}$ mice in comparison to the $\mathrm{P}_{0}{ }^{+/-} / \mathrm{TCR} \alpha^{+/-}$littermates $(42.1 \pm$ $6.3 \%$ vs $65.0 \pm 11.3 \%$ of total nerve area; $p<0.05)$. Also, myelin was thicker in $\mathrm{P}_{0}^{+/-} / \mathrm{TCR} \alpha^{-/-}$mice than in $\mathrm{P}_{0}^{+/-} / \mathrm{TCR} \alpha^{+/-}$ mice, although the differences between g-ratios were not statistically significant $(0.75 \pm 0.027$ vs $0.78 \pm 0.015)$. We also investigated the number of $\mathrm{F} 4 / 80$-positive macrophages in quadriceps nerves of $\mathrm{P}_{0}^{+/-} / \mathrm{TCR} \alpha^{-/-}$mice in comparison to the $\mathrm{P}_{0}^{+/-} /$ TCR $\alpha^{+/-}$littermates at 8 months of age. Similar to the findings in $\mathrm{P}_{0}{ }^{+/-} / \mathrm{RAG}-1^{-/-}$versus $\mathrm{P}_{0}^{+/-} / \mathrm{RAG}-1^{+/-}$mice, numbers of macrophages were reduced in the immune-deficient myelin mutants (Fig. 1, bottom diagram).

\section{Deficiency in the RAG-1 gene leads to less impaired conduction properties in $\mathrm{P}_{0}{ }^{+/-}$mice}

To test whether the immune system has an impact on conduction properties of peripheral nerves of $\mathrm{P}_{0}{ }^{+/-}$mutants, mice were subjected to an electrophysiological investigation by an examiner not aware of the genotypes.

In sciatic nerves of 13 -month-old $\mathrm{P}_{0}{ }^{+/+} / \mathrm{RAG}-1^{+/-}$and $\mathrm{P}_{0}{ }^{+/+} / \mathrm{RAG}-1^{-/-}$mice, conduction properties were comparable to those previously described for $\mathrm{P}_{0}{ }^{+/+}$mice (Zielasek et al., 1996; Fig. 3.). In both $\mathrm{P}_{0}^{+/-} / \mathrm{RAG}-1^{+/-}$and $\mathrm{P}_{0}{ }^{+/-} / \mathrm{RAG}-1^{-/-}$ mice, conduction properties were impaired when compared with littermates of $\mathrm{P}_{0}{ }^{+/+}$genotype. However, when comparing $\mathrm{P}_{0}{ }^{+/-} / \mathrm{RAG}-1^{+/-}$and $\mathrm{P}_{0}^{+/-} / \mathrm{RAG}-1^{-/-}$mice, the latter mutants showed better conduction properties. This was reflected by significantly shorter latencies of M-responses and of F-waves after distal or proximal stimulations (Fig. 3). Amplitudes of compound muscle action potentials were not significantly different in $\mathrm{P}_{0}^{+/-} /$ RAG- $1^{+/-}$versus $\mathrm{P}_{0}^{+/-} / \mathrm{RAG}-1^{-/-}$mutants $(13.9 \pm 4.1 \mathrm{mV}$ vs $11.8 \pm 3.7 \mathrm{mV}$ after distal stimulations; $n=4$ for each genotype).

\section{Deficiency in the TCR $\alpha$ gene leads to less impaired nerve conduction properties in $\mathrm{P}_{0}{ }^{+/-}$mice}

In addition, we investigated conduction properties in $\mathrm{P}_{0}^{+/+} /$ $\mathrm{TCR} \alpha^{+/-}, \quad \mathrm{P}_{0}^{+/+} / \mathrm{TCR} \alpha^{-/-}, \mathrm{P}_{0}^{+/-} / \mathrm{TCR} \alpha^{+/-}$, and $\mathrm{P}_{0}^{+/-}$ TCR $\alpha^{-1-}$ mice at 13 months of age. Similar to $\mathrm{P}_{0} / \mathrm{RAG}-1-$ mice, conduction properties in $\mathrm{P}_{0}^{+/-} / \mathrm{TCR} \alpha^{-/-}$mice were less affected than in $\mathrm{P}_{0}^{+/-} / \mathrm{TCR} \alpha^{+/-}$littermates. Motor nerve conduction velocities were significantly higher in the $\mathrm{P}_{0}{ }^{+/-} / \mathrm{TCR} \alpha^{-1-}$ mice ( $37 \pm 7 \mathrm{~m} / \mathrm{sec}$ vs $26 \pm 4 \mathrm{~m} / \mathrm{sec} ; p<0.05 ; n=3$ for each genotype). Other parameters, such as latencies of M-responses and of F-waves tended to show less impaired nerve conduction without reaching statistical significance, probably because of the low number of mice available (data not shown).

\section{Increased frequency of myelin-reactive splenocytes in $\mathrm{P}_{0}{ }^{+/-}$mice}

Based on the observation that the immune system appears to be involved in demyelination in $\mathrm{P}_{0}{ }^{+/-}$mice, we tested the hypothesis that in $\mathrm{P}_{0}{ }^{+/-}$mice an increased proportion of T-lymphocytes might recognize components of peripheral nerve myelin as autoantigens. We used the split-well technique (Pette et al., 1994) and compared the specific proliferative responses of isolated splenocytes from 8-month-old $\mathrm{P}_{0}{ }^{+/+}$and $\mathrm{P}_{0}{ }^{+/-}$mice, i.e., at an age of advanced myelin degeneration in $\mathrm{P}_{0}{ }^{+/-}$mice. Interestingly, the frequencies of cells proliferating in response to different myelin components were significantly higher in $\mathrm{P}_{0}{ }^{+/-}$versus $\mathrm{P}_{0}{ }^{+/+}$mice (Fig. 4). By contrast, stimulation with concanavalin A caused comparable proliferative responses in both $\mathrm{P}_{0}{ }^{+/+}$and $\mathrm{P}_{0}^{+/-}$mice (Fig. 4).

\section{DISCUSSION}

In the present study, we demonstrate that in a mouse model for hereditary neuropathies, demyelination is less severe when the immune system is impaired. Removal of mature T-lymphocytes and amelioration of the pathological phenotype was achieved by two different genetic immune defects (RAG-1 $1^{-/-}$and TCR $\alpha^{-/-}$) thus supporting a role of the immune system in the demyelinating phenotype of $\mathrm{P}_{0}{ }^{+/-}$mice. Another and independent argument in favor of this view is the observation that in splenocyte preparations from $\mathrm{P}_{0}{ }^{+/-}$mice the frequencies of leukocytes proliferating in response to myelin components was higher than in preparations from $\mathrm{P}_{0}{ }^{+/+}$mice. Although we did not investigate the cytokine release of these myelin-specific T-lymphocytes, we suggest that the elevated frequency of proliferating T-lymphocytes in $\mathrm{P}_{0}{ }^{+/-}$ mice reflects the involvement of the immune system in the myelin pathology of $\mathrm{P}_{0}{ }^{+/-}$mice. The highest frequency of proliferating cells was observed when $\mathrm{P}_{0}$ was offered to leukocytes from $\mathrm{P}_{0}{ }^{+/-}$ mice. Why $\mathrm{P}_{0}$ appears to be a main immunogenic component in $\mathrm{P}_{0}{ }^{+/-}$mice is presently not known. In experimental autoimmune neuritis (EAN) in rat, $\mathrm{P}_{2}$ is a much stronger neuritogen than $\mathrm{P}_{0}$ (Linington et al., 1992), but there might be differences among species. On the other hand, even in heterozygous mutants, $\mathrm{P}_{0}$ is still the most abundant peripheral myelin protein (Giese et al., 1992) which could explain a substantial role of $P_{0}$ as an immunogenic component. This does not preclude the possibility that other myelin components that have not been tested could elicit even stronger immune responses.

The mechanism leading to an involvement of the immune system during demyelination in $\mathrm{P}_{0}{ }^{+/-}$mice is presently not known. It is possible that the reduction of $P_{0}$ may result in an intrinsic instability of myelin leading to an initial attraction of 


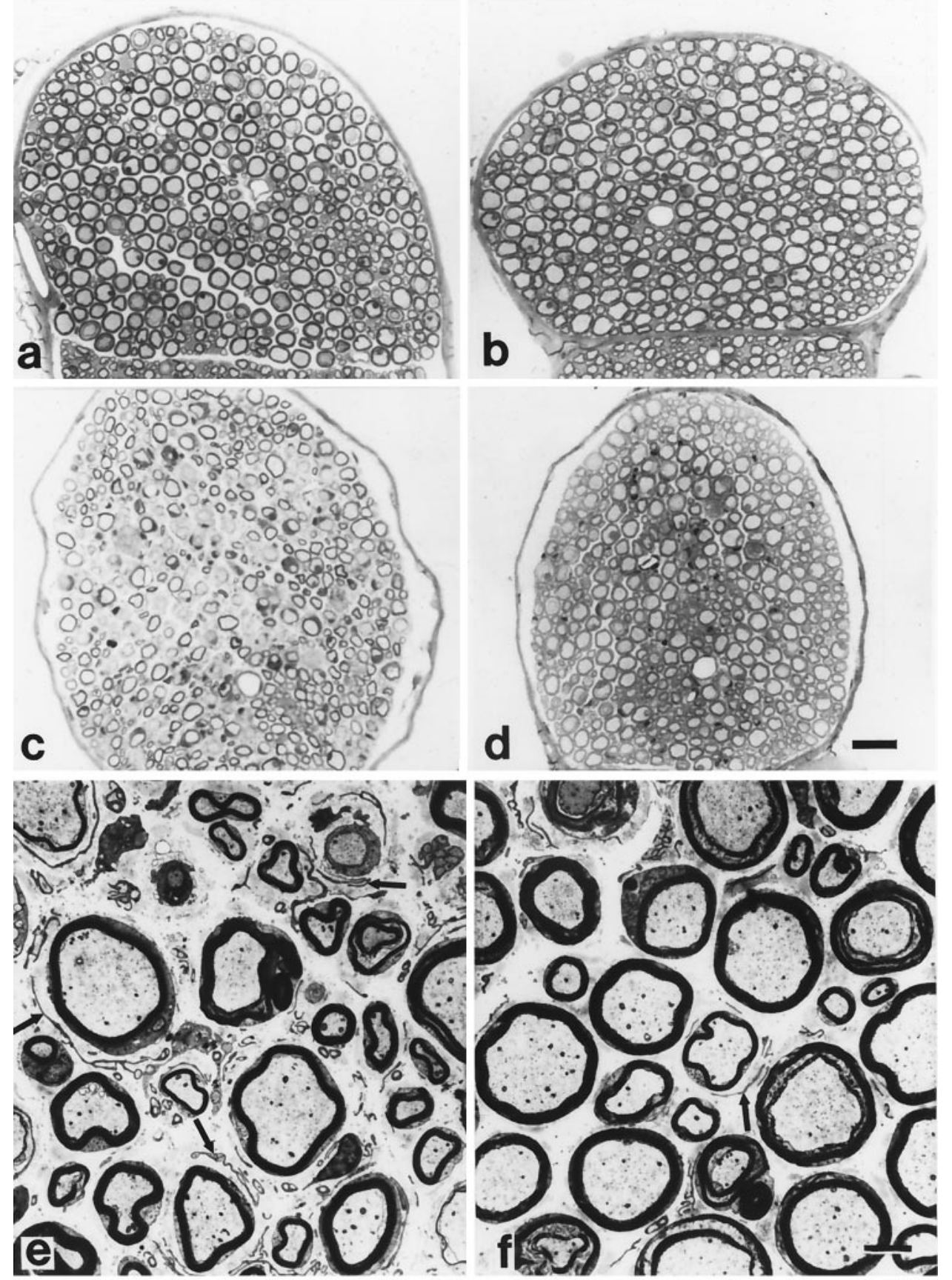

Figure 2. Representative semithin cross sections of femoral quadriceps nerves from $\mathrm{P}_{0}^{+/+} / \mathrm{RAG}^{+1 /-}(a), \mathrm{P}_{0}^{+/+} / \mathrm{RAG}^{+1} 1^{-1}$ (b), $\mathrm{P}_{0}^{+/-} / \mathrm{RAG}_{-1}^{+l-}(c)$, and $\mathrm{P}_{0}^{+/-} /$ RAG-1 $1^{-1-}$ mice $(d)$ and ultrathin cross sections of femoral quadriceps nerves from $\mathrm{P}_{0}^{+/-} / \mathrm{RAG}^{+1} 1^{+/}(e)$ and $\mathrm{P}_{0}^{+/-} / \mathrm{RAG}^{+}$ $1^{-/-}$mice $(f)$ at the age of 13 months. In $\mathrm{P}_{0}{ }^{+/-} / \mathrm{RAG}^{+1-} 1^{+/}$mice $(c, e)$, numerous thinly myelinated and demyelinated axons are visible as well as extended endoneurial spaces with supernumerary Schwann cells (e, f, arrows). In $\mathrm{P}_{0}{ }^{+/-} / \mathrm{RAG}-1^{-1-}$ mice $(d$, $f$ ), these pathological characteristics are less pronounced. Note normal appearance of axon-Schwann cell units in $\mathrm{P}_{0}{ }^{+}$ $+/ \mathrm{RAG}^{+} 1^{+/-}(a)$ and $\mathrm{P}_{0}{ }^{+/+} / \mathrm{RAG}^{-1}$ mice $(b)$. Scale bars: $a-d, 20 \mu \mathrm{m}$ (in $d$ ); $e$, $f, 5 \mu \mathrm{m}$ (in $f$ ). macrophages by Schwann cell-derived cytokines followed by a macrophage-mediated attraction of T-lymphocytes. An argument in favor of this model is our observation that the number of macrophages is increased already at 4 months of age in $\mathrm{P}_{0}{ }^{+/-}$ mice, whereas the number of $\mathrm{T}$ cells is not yet elevated at this age. The activation of autoimmune T-lymphocytes by antigenpresenting macrophages could eventually result in a local cascade of cellular and humoral immune reactions leading to demyelination (Gold et al., 1999) and/or to a continued attraction and activation of macrophages by T-lymphocyte-derived cytokines. The reduced numbers of macrophages in the less impaired nerves of immune-deficient myelin mutants could indicate a devastating role of macrophages during genetically induced demyelination, as is the case in primarily immune-mediated disorders of the nervous system, such as EAE and EAN (Huitinga et al., 1990; Jung et al., 1993). However, it is still possible that the lower number of macrophages is rather the consequence of than the cause for a less severe pathological status of the immune deficient myelin mutants. Thus, further studies are needed to characterize the roles of macrophages in genetically mediated demyelination.

In contrast to acute and primarily immune-mediated disorders, such as EAN, we observed only few T-lymphocytes within the nerve. As mentioned above, activated T-lymphocytes can lead to a significant damage by direct cytotoxicity or by T-cell-derived signals attracting other immune cells, such as macrophages. In addition, chronic instability of myelin induced by a gene defect 
Proximal M-Response Latency

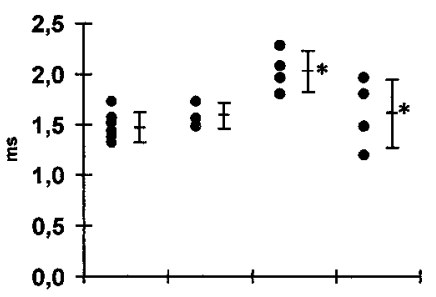

Proximal F-Wave Latency
Distal M-Response Latency

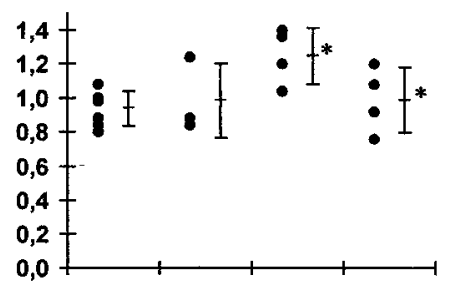

Distal F-Wave Latency

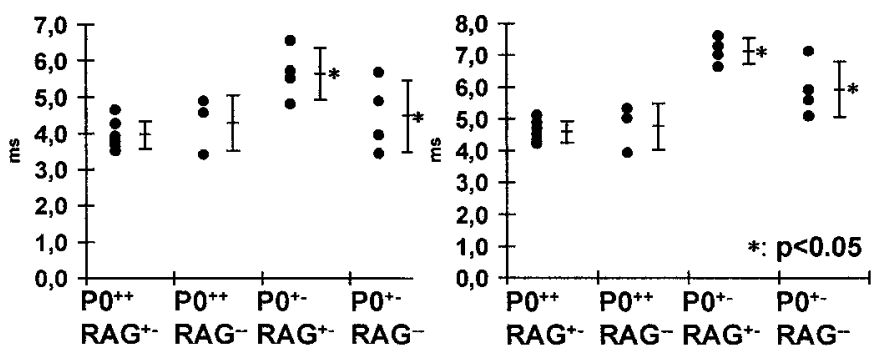

Figure 3. Schematic representation of parameters of conduction properties of sciatic nerves of $\mathrm{P}_{0}^{+/+} / \mathrm{RAG}-1^{+/-}, \mathrm{P}_{0}^{+/+} / \mathrm{RAG}^{+1} 1^{-/-}, \mathrm{P}_{0}^{+/-} /$ RAG- $1^{+/-}$, and $\mathrm{P}_{0}^{+/-} / \mathrm{RAG}-1^{-/-}$mice (asterisks). Note that in $\mathrm{P}_{0}^{+-/}$ RAG-1 ${ }^{-1-}$ mice, nerve conduction properties are significantly improved when compared to values from $\mathrm{P}_{0}{ }^{+/-} / \mathrm{RAG}-1^{+/-}$mice. Each black dot represents the value of one sciatic nerve from one single mouse investigated; short horizontal bars represent mean values \pm SDs.

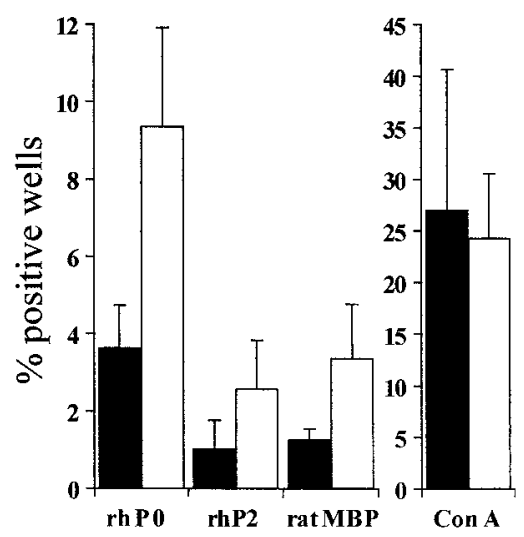

Figure 4. Schematic representation of the proliferative response of splenocytes from 8-month-old $\mathrm{P}_{0}{ }^{+/+}$(filled bars) and $\mathrm{P}_{0}{ }^{+/-}$mice (open bars) to myelin components and to concanavalin A. Stimulation of isolated splenocytes from $\mathrm{P}_{0}{ }^{+/+}$or $\mathrm{P}_{0}{ }^{+/-}$mice by different myelin antigens was performed by split-well technique. Each column represents the mean of the percentage of positive wells of four mice \pm SEM. All myelin components tested elicited a higher proliferative response in $\mathrm{P}_{0}{ }^{+/-}$versus $\mathrm{P}_{0}{ }^{+/+}$mice, and statistical significance $(p<0.05)$ was achieved when the proliferative responses against the three myelin components were summed up. Stimulation with concanavalin A $($ Con $A)$ was taken as positive control for the proliferative capacity of splenocytes from $\mathrm{P}_{0}^{+/+}$ and $\mathrm{P}_{0}{ }^{+/-}$mice.

may favor the perpetuation of immune reactions to self by repeated exposure of antigen or antigens toward patrolling T-lymphocytes. Furthermore, Schwann cells of $\mathrm{P}_{0}{ }^{+/-}$mice with an intrinsically reduced stability of myelin might react very sensitive to a mild inflammatory attack carried by low numbers of cells. An alternative interpretation could be that the relatively few lymphocytes in the diseased nerve are not the only culprits leading to an aggravation of the pathology. It is possible that mice deficient in the immune system may generally express lower levels of gliotoxic cytokines than mice with a wild-type immune system and that the intrinsically instable Schwann cells of $\mathrm{P}_{0}{ }^{+/-}$mice react particularly sensitive on such cytokines.

A relevant question concerns the clinical implications of our findings. Most forms of $\mathrm{P}_{0}$-related hereditary neuropathies are caused by heterozygous mutations that only seldom result in a pure reduction of gene dosis (Scherer and Chance, 1995; Warner et al., 1996). Rather, toxic gain-of-function and dominantnegative effects might be the leading detrimental mechanisms in most of the $\mathrm{P}_{0}$-mutation-mediated disorders (Warner et al., 1996; Wong and Filbin, 1996; Scherer, 1997; Zhang and Filbin, 1998). This, however, does not argue against the possibility that in patients suffering from such detrimental processes immunemediated mechanisms are involved as a secondary cause as we have shown for the $\mathrm{P}_{0}{ }^{+/-}$mice. Rather, it is plausible to assume that the involvement of the immune system as an aggravating component is not confined to hereditary neuropathies caused by $\mathrm{P}_{0}$-mutations, but might be widespread among the different types of hereditary neuropathies. Interestingly, in a variety of CMT patients of unknown genotype, elevated levels of activated T-lymphocytes have been detected in the peripheral blood (Williams et al., 1987, 1992). Furthermore, some patients are reported to develop a sudden worsening of their clinical neuropathy and show inflammatory infiltrates in nerve biopsies (Malandrini et al., 1999) and clinically respond to corticosteroids (Dyck et al., 1993). Taking into consideration that immune reactions can be superimposed on the clinical and pathological phenotype of CMT, it might be worthwhile to investigate whether among patients with chronic inflammatory demyelinating polyradiculopathy some might carry CMT mutations that would lead to a more pronounced immune reaction. In analogy, it is intriguing to speculate that mutations in myelin and other genes of the CNS could elicit similar immune reactions that could manifest themselves in multiple sclerosis and modulate the disease course.

Our finding that in $\mathrm{P}_{0}{ }^{+/-}$mice, the immune system contributes to demyelination might offer the possibility to understand the pathological mechanisms of demyelination in at least some forms of inherited neuropathies. It might, therefore, be worthwhile to reconsider treatment strategies with appropriate immunomodulators or suppressors to ameliorate the immune-mediated pathological components of the still untreatable monogenic disorders. In addition, the knowledge about the participation of the immune system in primarily genetically based neuropathies might extend our understanding of the pathomechanisms occurring in neurodegenerative disorders in general.

\section{REFERENCES}

Austin JM, Gordon S (1981) A monoclonal antibody directed specifically against the mouse macrophage. Eur J Immunol 10:805-815.

Brideau RJ, Carter PB, McMaster WR, Mason DW, Williams AF (1980) Two subsets of rat $\mathrm{T}$ lymphocytes defined with monoclonal antibodies. Eur J Immunol 10:609-615.

Carenini S, Montag D, Cremer H, Schachner M, Martini R (1997) Absence of the myelin-associated glycoprotein (MAG) and the neural cell adhesion molecule (N-CAM) interferes with the maintenance, but not with the formation of peripheral myelin. Cell Tissue Res 287:3-9.

Cobbold SP, Jayasuriya A, Nash A, Prospero TD, Waldmann H (1984) Therapy with monoclonal antibodies by elimination of T-cell subsets in vivo. Nature 312:548-551.

De Jonghe P, Timmerman V, Nelis E, Martin JJ, Van Broeckhoven C (1997) Charcot-Marie-Tooth disease and related peripheral neuropathies. J Periph Nerv Syst 2:370-387.

Dyck PJ, Chance P, Lebo R, Carney JA (1993) Hereditary motor and 
sensory neuropathies. In: Peripheral Neuropathy (Dyck PJ, Thomas PK, Griffin JW, Low PA, and Poduslo JF, eds), pp 1094-1136. Philadelphia: WB Saunders.

Friede RL (1972) Control of myelin formation by axon caliber (with a model of the control mechanism). J Comp Neurol 233-252.

Gabreëls-Festen AA, Hoogendijk JE, Meijerink PH, Gabreëls FJ, Bolhuis PA, van Beersum S, Kulkens T, Nelis E, Jennekens FG, de Visser M, van Engelen BG, Van Broeckhoven C, Mariman EC (1996) Two divergent types of nerve pathology in patients with different $\mathrm{P}_{0}$ mutations in Charcot-Marie-Tooth disease. Neurol 47:761-765.

Giese KP, Martini R, Lemke G, Soriano P, Schachner M (1992) Mouse $\mathrm{P}_{0}$ gene disruption leads to hypomyelination, abnormal expression of recognition molecules, and degeneration of myelin and axons. Cell 71:565-576.

Gold R, Archelos JJ, Hartung H-P (1999) Mechanisms of immune regulation in the peripheral nervous system. Brain Pathol 9:343-360.

Guénard V, Schweitzer B, Flechsig E, Hemmi S, Martini R, Suter U, Schachner M (1999) Effective gene transfer of lacZ and $P_{0}$ into Schwann cells of $\mathrm{P}_{0}$-deficient mice. Glia 25:165-178.

Huitinga I, v Rooijen N, Groot CJA, Uitdehaag BMJ, Dijkstra CD (1990) Suppression of experimental allergic encephalomyelitis in Lewis rats after elimination of macrophages. J Exp Med 172:1025-1033.

Jung S, Huitinga I, Schmidt B, Zielasek J, Dijkstra CD, Toyka KV, Hartung HP (1993) Selective elimination of macrophages by dichlormethylene diphosphonate-containing liposomes suppresses experimental autoimmune neuritis. J Neurol Sci 119:195-202.

Lindberg RLP, Martini R, Baumgartner M, Erne B, Borg J, Zielasek J, Ricker K, Steck A, Toyka KV, Meyer UA (1999) Motor neuropathy in porphobilinogen deaminase-deficient mice imitates the peripheral neuropathy of human acute porphyria. J Clin Invest 103:1127-1134.

Linington C, Lassmann H, Ozawa K, Kosin S, Mongan L (1992) Cell adhesion molecules of the immunoglobulin supergene family as tissuespecific autoantigens: induction of experimental allergic neuritis (EAN) by $\mathrm{PO}$ protein-specific $\mathrm{T}$ cell lines. Eur $\mathrm{J}$ Immunol 22:1813-1817.

Malandrini A, Villanova M, Dotti MT, Frederico A (1999) Acute inflammatory neuropathy in Charcot-Marie-Tooth disease. Neurology 52:859-861.

Martini R (1997) Animal models for inherited peripheral neuropathies. J Anat 191:321-336.

Martini R, Schachner M (1997) Molecular bases of myelin formation as revealed by investigations on mice deficient in glial cell surface molecules. Glia 19:298-310.

Martini R, Zielasek J, Toyka KV, Giese KP, Schachner M (1995a) Protein zero $\left(\mathrm{P}_{0}\right)$-deficient mice show myelin degeneration in peripheral nerves characteristic of inherited human neuropathies. Nat Genet 11:281-286.

Martini R, Mohajeri MH, Kasper S, Giese KP, Schachner M (1995b) Mice doubly deficient in the genes for $\mathrm{P}_{0}$ and myelin basic protein show that both proteins contribute to the formation of the major dense line in peripheral nerve myelin. J Neurosci 15:4488-4495.

Martini R, Zielasek J, Toyka KV (1998) Inherited demyelinating neuropathies: from gene to disease. Curr Opin Neurol 11:545-556.

Mombaerts P, Iacomini J, Johnson RS, Herrup K, Tonegawa S, Papaioannou VE (1992) RAG-1-deficient mice have no mature B and T lymphocytes. Cell 68:869-877.

Nelis E, Haites N, Van Broeckhoven C (1999) Mutations in the peripheral myelin genes and associated genes in inherited peripheral neuropathies. Hum Genet 13:11-28.

Neuhaus O, Emoto M, Kaufmann SH (1996) Constitutive biological activity of thymus-independent TCR-alpha-beta+ intestinal intraepithelial lymphocytes in TCR-alpha-/- gene disruption mice. Immunol Lett 54:53-57.
Pette M, Fujita K, Wilkinson D, Altmann DM, Trowsdale J, Giegerich G, Hinkkanen A, Epplen JT, Kappos L, Wekerle H (1990) Myelin autoreactivity in multiple sclerosis: recognition of myelin basic protein in the context of HLA-DR2 products by T lymphocytes of multiplesclerosis patients and healthy donors. Proc Natl Acad Sci USA 87:7968-7972.

Pette M, Linington C, Gengaroli C, Grosse-Wilde H, Toyka KV, Hartung HP (1994) T lymphocyte recognition sites on peripheral nerve myelin $\mathrm{P}_{0}$ protein. J Neuroimmunol 54:29-34.

Philpott KL, Viney JL, Kay G, Rastan S, Gardiner EM, Chae S, Hayday AC, Owen MJ (1992) Lymphoid development in mice congenitally lacking $\mathrm{T}$ cell receptor alpha beta-expressing cells. Science 256:1448-1452.

Scherer SS (1997) Molecular genetics of demyelination: new wrinkles on an old membrane. Neuron 18:13-16.

Scherer SS, Chance PF (1995) Myelin genes: getting the dosage right. Nat Genet 11:226-228.

Schmid CD, Schnell L, Schachner M, Martini R (1996) Peripheral nerves of a mouse model for Charcot-Marie-Tooth neuropathy $1 \mathrm{~B}$ show infiltration of macrophages and CD4- and CD8-positive lymphocytes. Soc Neurosci Abstr 22:835.819.

Schmidt B, Toyka KV, Kiefer R, Full J, Hartung HP, Pollard J (1996) Inflammatory infiltrates in sural nerve biopsies in Guillain-Barre syndrome and chronic inflammatory demyelinating neuropathy. Muscle Nerve 19:474-487.

Shy ME, Arroyo E, Sladky J, Menichella D, Jiang H, Xu W, Kamholz J, Scherer SS (1997) Heterozygous $\mathrm{P}_{0}$ knockout mice develop a peripheral neuropathy that resembles chronic inflammatory demyelinating polyneuropathy (CIDP). J Neuropathol Exp Neurol 56:811-821.

Stienekemeier M, Herrmann T, Kruse N, Weishaupt A, Weilbach FX, Giegerich G, Theofilopoulos A, Jung S, Gold R (1999) Heterogeneity of T-cell receptor usage in experimental autoimmune neuritis in the Lewis rat. Brain 122:523-535.

Tachi N, Kozuka N, Ohya K, Chiba S, Sasaki K (1997) Tomaculous neuropathy in Charcot-Marie-Tooth disease with myelin protein zero gene mutation. J Neurol Sci 153:106-109.

Thomas FP, Lebo RV, Rosoklija G, Ding XS, Lovelace RE, Latov N, Hays, AP (1994) Tomaculous neuropathy in chromosome 1 CharcotMarie-Tooth syndrome. Acta Neuropathol (Berl) 87:91-97.

Warner LE, Hilz MJ, Appel SH, Killian JM, Kolodny EH, Karpati G, Carpenter S, Watters GV, Wheeler C, Witt D, Bodell A, Nelis E, Van Broeckhoven C, Lupski JR (1996) Clinical phenotypes of different MPZ $\left(\mathrm{P}_{0}\right)$ mutations may include Charcot Marie Tooth type 1B, Dejerine Sottas, and congenital hypomyelination. Neuron 17:451-460. Weishaupt A, Giegerich G, Jung S, Gold R, Enders U, Pette M, Hayasaka K, Hartung HP, Toyka KV (1995) T cell antigenic and neuritogenic activity of recombinant human peripheral myelin P2 protein. J Neuroimmunol 63:149-156.

Williams LL, Shannon BT, O’Dougherty M, Wright FS (1987) Activated $\mathrm{T}$ cells in type I Charcot-Marie-Tooth disease: evidence for immunologic heterogeneity. J Neuroimmunol 16:317-330.

Williams LL, Kissel JT, Shannon BT, Wright FS, Mendell JR (1992) Expression of Schwann cell and peripheral T-cell activation epitopes in hereditary motor and sensory neuropathy. J Neuroimmunol 36:147-155.

Wong MH, Filbin MT (1996) Dominant-negative effect on adhesion by myelin $\mathrm{P}_{0}$ protein truncated in its cytoplasmic domain. J Cell Biol 134:1531-1541.

Zhang K, Filbin MT (1998) Myelin Po protein mutated at Cys21 has a dominant-negative effect on adhesion of wild type Po. J Neurosci Res $53: 1-6$.

Zielasek J, Martini R, Toyka KV (1996) Functional abnormalities in $\mathrm{P}_{0}$-deficient mice resemble human hereditary neuropathies linked to $\mathrm{P}_{0}$ gene mutations. Muscle Nerve 19:946-952. 